\title{
PENERAPAN MODEL PBL PADA PELAJARAN BIOLOGI UNTUK MENINGKATKAN KOMPETENSI DAN KEMAMPUAN BERPIKIR KRITIS SISWA KELAS X
}

\author{
Fitri \\ SMAN 19 Bandung \\ Jl. Ir. H. Juanda (Dao Pojok), Bandung, Jawa Barat \\ Telp: (022) 2502465
}

\begin{abstract}
Abstrak
Penelitian ini bertujuan untuk meningkatkan kemampuan berpikir kritis siswa dengan menggunakan PBL. Penelitian ini dilaksanakan di SMA Negeri 19 Bandung. Subjek penelitian ini adalah siswa kelas X, Objek penelitian ini adalah (1) model PBL; (2) kemampuan berpikir kritis siswa; sikap siswa terhadap pelajaran Biologi; dan (3) kemampuan menerapkan konsep Biologi;. Penelitian ini merupakan Penelitian Tindakan Kelas (PTK) yang dilaksanakan dalam dua siklus penelitian. Penelitian masing-masing siklus dilaksanakan melalui empat tahapan, yaitu (1) perencanaan penelitian; (2) pelaksanaan tindakan; (3) observasi/ evaluasi; dan (4) refleksi. Hasil penelitian menunjukkan siklus I $23,80 \%$ siswa belum tuntas. Hal ini disebabkan siswa yang sebelumnya belum pernah mengikuti pelajaran dengan model ini, yang menuntut siswa benar-benar mandiri dan aktif dalam menggali materi pelajarannya. Sedangkan ketuntasan klasikal 91,64\%. Hal ini disebabkan oleh kelas X MIA 6 merupakan kelas dengan siswa yang yang memiliki kemampuan akademis lebih baik berdasarkan atas masukannya. Pada siklus II, kedua kelas menunjukkan ketuntasan klasikal sangat baik $(95,71 \%$ dan 98,64 \% dengan rerata 80,12 dan 83,43). Hal ini berarti, setelah siswa belajar lebih dari 1,5 bulan di siklus I, siswa telah mampu mengikuti pelajaran dengan model PBL ini. Dari hasil penelitian ini dapat dijelaskan bahwa, dengan menerapkan model PBL dalam pelajaran Biologi, pemahaman konsep Biologi kelas X MIA 5 dan kelas X MIA 6 meningkat.
\end{abstract}

Kata kunci: PBL, Berpikir Kritis, Penerapan Konsep Biologi

\begin{abstract}
The aims of this research are to improve students' critical thinking skills by using PBL model. This research was conducted at SMA Negeri 19 Bandung.The subjects were students of class X, an the research object - were (1) PBL model; (2) Students' critical thinking skills; students' attitudes towards biology; and (3) the ability to apply the concept of Biology;. This research is Penelitian Tindakan Kelas (PTK) that was conducted in two cycles of research. Each cycle of the research was conducted through four stages: (1) research planning; (2) implementation of the action; (3) observation/evaluation; and (4) reflection. The results showed $23.80 \%$ the first cycle students have not been completed. This is due to students who had never participated the lesson with this model, requires students truly independent and actively explore the lesson material. While the classical completeness approximately $91.64 \%$. This is due to class X MIA 6 is a class with students who have better academic ability based on their input. In the second cycle, Both of classes showed excellent classical completeness (95.71\% and $98.64 \%$ with a mean of 80.12 and 83.43). This means, students who have learned more than 1.5 months in the first cycle, have been able to follow the lessons with this PBL models. The result showed that the implementation of PBL model in Biology lessons increases Understanding the concept of Biology for students in class 5 and class X MIA 6
\end{abstract}

Keywords: PBL, Critical Thinking, Applying the concept of Biology

\section{Pendahuluan}

Kurikulum 2013 sudah dilaksanakan di SMA Negeri 19 Bandung sejak tahun pelajaran 2014/2015. Pada Kurikulum Nasional terdapat beberapa perbedaan dari kurikulum sebelumnya diantaranya adalah pergeseran pola pikir dari pemikiran faktual ke pemikiran kritis (membutuhkan pemikiran kreatif ).

Menurut Pusat Kurikulum (2006), kegiatan belajar mengajar hendaknya (1) memberikan peluang bagi siswa untuk mencari, mengolah, dan menemukan sendiri pengetahuannya di 
bawah bimbingan guru atau orang dewasa, (2) merupakan pola yang mencerminkan ciri khas dalam pengembangan keterampilan dasar mata pelajaran yang bersangkutan, misalnya observasi lingkungan sekitar, penyelidikan/eksperimen, pemecahan masalah, simulasi, wawancara dengan narasumber, pengembangan teknologi, penggunaan peta dan foto, pemanfaatan kliping, dan sumber belajar lainnya, (3) disesuaikan dengan ragam sumber belajar dan sarana belajar yang tersedia, (4) bervariasi dengan mengkombinasikan antara kegiatan belajar perseorangan, pasangan, kelompok, dan klasikal, dan (5) memperhatikan pelayanan terhadap perbedaan individual siswa seperti bakat, kemampuan minat, latar belakang keluarga, sosial ekono$\mathrm{mi}_{2}$ dan budaya siswa yang bersangkutan.

Pendidikan Biologi SMA menekankan pada pemberian pengalaman secara langsung. Karena itu, siswa perlu dibantu untuk mengem-bangkan sejumlah keterampilan proses supaya mereka mampu menjelajahi dan memahami alam sekitar. Keterampilan ini meliputi keteram-pilan mengamati dengan seluruh indera, mengajukan hipotesis, menggunakan alat dan bahan secara benar dengan selalu mempertimbangkan keselamatan kerja, mengajukan pertanyaan, menggolongkan, menafsirkan data, mengkomunikasikan hasil temuan, menggali, dan memilah informasi faktual yang relevan untuk menguji gagasan-gagasan atau memecahkan masalah sehari-hari. Pada dasarnya, pelajaran Biologi berupaya membekali siswa dengan berbagai kemampuan tentang cara "mengetahui" dan cara "mengerjakan" yang dapat membantu siswa untuk memahami alam sekitar secara mendalam (Pusat Kurikulum, 2002).

Berpikir adalah kegiatan mental dalam memecahkan masalah (Gagne, 1980). Liliasari (2000) membedakan kemampuan berpikir dasar dan kemampuan berpikir tingkat tinggi. Johnson (2002); Krulik and Rudnick (1996) mengemukakan berpikir tingkat tinggi meliputi berpikir kreatif dan berpikir kritis. Berpikir kreatif adalah aktivitas mental untuk mengembangkan atau menemukan ide-ide asli (orisinil), estetis, konstruktif yang berhubungan dengan pandang-an konsep, dan menekankan pada aspek berpikir intuitif dan rasional, sedangkan berpikir kritis adalah proses terorganisir yang melibatkan aktivitas mental dalam memecahkan masalah, pengambilan keputusan, analisis asumsi, dan inkuiri sains. Enis (1985) dan Marzano (1988) mengemukakan, berpikir kritis meliputi komponen - komponen, (1) merumuskan masalah, (2) memberikan argumen terhadap masalah, (3) melakukan deduksi, (4) melakukan induksi, (5) melakukan evaluasi, dan (6) mengambil keputusan serta melaksanakan.

Kurikulum Nasional telah diberlakukan di SMA Negeri 19 Bandung sejak tahun pelajaran 2014/2015. Namun, pelaksanaan pelajarannya maupun hasil belajar siswa masih belum sesuai dengan harapan Kurikulum Nasional. Permasalahan-permasalahan pembelajaran Biologi yang dapat diidentifikasi oleh guru Biologi di SMA Negeri 19 Bandung adalah sebagai berikut. (1) Pelaksanaan pembelajaran masih seperti pembelajaran pada Kurikulum KBK, yaitu berpusat pada guru (teacher centered) yang menggunakan model pembelajaran tradisional yang dasar filosofinya lebih pada behaviorisme. (2) Pembelajaran Biologi yang dilaksanakan belum terbiasa mengkaitkan materi pelajaran dengan keadaan kehidupan sehari-hari siswa. Guru lebih banyak membahas teori-teori yang ada dalam buku dan memberikan contoh-contoh yang ada dalam buku teks yang disusun di Jakarta dan daerah lain yang belum tentu sesuai dengan keadaan yang ada di Bandung (3) Masih sulitnya penentuan model-model pembelajaran yang harus digunakan untuk meningkatkan kompetensi siswa sesuai tuntutan Kurikulum Nasional karena masih terbatasnya pemahaman guru terhadap model-model pembelajaran inovatif. (4) Masih adanya kesulitan dalam menerapkan sistem evaluasi, terutama menerapkan penilaian autentik (authentic assesment) karena kurangnya 
pemahaman dan kemampuan guru dalam menerapkan sistem penilaian autentik tersebut. (5) Standar Kompetensi Minimal (SKM) individual siswa terhadap penguasaan suatu Kompetensi Dasar (KD) pada mata pelajaran Biologi di SMA Negeri 19 Bandung ditetapkan cukup tinggi, yaitu $75 \%$. Untuk memenuhi tuntutan itu, guru menemui kesulitan. Dalam satu kali proses pembelajaran, siswa yang mampu melewati SKM ini dengan rerata $50 \%$ dari jumlah siswa dalam setiap kelas. Oleh karena itu, guru harus menyelenggarakan beberapa kali kegiatan remidial (kegiatan memerlukan waktu dan tenaga) agar semua siswa tuntas dalam setiap KD. (6) Sampai saat ini, kecakapan berpikir siswa, terutama kecakapan berpikir kritis, belum ditangani oleh guru. Hal ini disebabkan oleh kurangnya pengetahuan guru terhadap model pembelajaran yang dapat melatih kecakapan berpikir, belum diketahuinya bahwa kecakapan berpikir dapat dilatih, dan belum diketahuinya cara mengukur kecakapan berpikir kritis. Hal ini dapat disampaikan bahwa latihan berpikir tidak direncanakan, sehingga berakibat rendahnya kemampuan siswa dalam memecahkan masalah riil kehidupan dan kemampuan mengambil keputusan.

Uraian di atas menunjukkan adanya masalah pembelajaran yang berupa kesenjangan antara proses dan hasil belajar pada pembelajaran Biologi yang diharapkan oleh kurikulum 2013 dan para ahli pendidikan dengan pembelajaran yang dilaksanakan oleh guru Biologi di SMA Negeri 19 Bandung. Oleh karena itu, perlu diadakan usaha perbaikan proses pembelajaran dengan menerapkan model-model pembelajaran inovatif. Model pembelajaran yang dipilih dalam penelitian ini untuk meningkatkan kompetensi siswa dan kemampuan berpikir kritis adalah Model Belajar Berdasarkan Masalah atau Problem-Based Learning (PBL).

Belajar berdasarkan masalah atau PBL adalah model pembelajaran yang dasar filosofinya konstruktivisme. PBL dirancang berdasar- kan masalah riil kehidupan yang bersifat illstructured, terbuka, dan mendua (Forgaty, 1997; Jones, 1996). PBL dapat membangkitkan minat siswa, nyata, dan sesuai untuk membangun kemampuan intelektual. Hasting (2001) mengemukakan PBL dapat meningkatkan pemahaman siswa terhadap materi yang dipelajari, kemampuan memecahkan masalah, dan keterampilan menerapkan konsep. Rindell (1999); Wheeler (2002); Arnyana (2005) menemukan, bahwa PBL dapat melatih kecakapan berpikir tingkat tinggi siswa.

Menurut Ibrahim dan Nur (2000) dan Ismail (2002), PBL memiliki ciri-ciri sebagai berikut. (1) Mengajukan pertanyaan atau masalah. (2) Berfokus pada keterkaitan antardisiplin. (3) Penyelidikan autentik. (4) Menghasilkan produk/karya dan memamerkannya. (5) Kerja sama. PBL biasanya terdiri dari lima tahap utama (sintaks), yaitu: (1) orientasi siswa terhadap masalah autentik, (2) mengorganisasi siswa dalam belajar, (3) membantu siswa secara individual atau kelompok dalam menlaksanakan penyelidikan, (4) mengembangkan dan menyajikan hasil karya, dan (5) analisis dan evaluasi proses pemecahan masalah (Arends, 2004: 406).

Berdasarkan latar belakang dan identi-fikasi masalah yang diuraikan di atas terdapat masalah -masalah yang akan diupayakan pemecahannya melalui Penelitian Tindakan Kelas (Classroom Action Research). Masalah-masalah itu adalah (a) pentingnya peningkatan penguasaan kompetensi siswa dalam pelajaran Biologi, yaitu menyangkut tentang pemahaman konsep Biologi, kemampuan memecahkan masalah Biologi, kemampuan menerapkan konsep-konsep Biologi, dan sikap siswa terhadap pelajaran Biologi, dan (b) pentingnya peningkatan kemampuan berpikir kritis siswa. Masalah-masalah tersebut dipecahkan dengan menerapkan model PBL. Berdasarkan masalah-masalah tersebut dan cara pemecahan yang diajukan, maka rumusan masalah yang dikemukakan dalam penelitian tindakan kelas ini adalah (1) apakah penerapan model 
Belajar Berdasarkan Masalah atau Problem Based Learning $(P B L)$ dapat meningkatkan pemahaman konsep Biologi?; (2) apakah penerapan model PBL dapat meningkatkan kemampuan memecahkan masalah Biologi?; (3) apakah penerapan model PBL dapat meningkatkan kemampuan menerapkan konsep-konsep Biologi dalm kehidupan riil?; (4) apakah penerapan model PBL dapat meningkatkan sikap siswa terhadap pelajaran Biologi?; dan (5) apakah penerapan model PBL dapat meningkatkan kemampuan berpikir kritis siswa?

Tujuan dari penelitian ini adalah (1) meningkatkan pemahaman konsep Biologi dengan menerapkan model PBL, (2) meningkatkan kemampuan memecahkan masalah Biologi dengan menerapkan model PBL, (3) meningkatkan kemampuan menerapkan konsep-konsep Biologi dengan menerapkan model PBL, (4) meningkatkan sikap siswa terhadap pelajaran Biologi dengan menerapkan model PBL, dan (5) meningkatkan kemampuan berpikir kritis siswa dengan menerapkan model PBL.

\section{Metode Penelitian}

Penelitian ini dilaksanakan di SMA Negeri 19 Bandung. Waktu pelaksanaannya: Juli-Oktober 2014. Penelitian ini dilaksanakan pada mata pelajaran Biologi kelas X.

Subjek penelitian ini adalah siswa kelas $\mathrm{X}$ SMA Negeri 19 Bandung pada semester I tahun pelajaran 2014/2015, yaitu kelas X MIPA 5 dan kelas X MIA 6. Variabel dalam penelitian ini adalah (1) model PBL; (2) kemampuan berpikir kritis siswa; sikap siswa terhadap pelajaran Biologi; 3) kemampuan menerapkan konsep Biologi; dan (4) kemampuan memecahkan masalah Biologi.

Penelitian ini merupakan Penelitian Tindakan Kelas (PTK) dengan mengikuti model yang dikembangkan oleh Kemmis and McTagart (1988) dan McNiff (1992). Penelitian tindakan kelas ini dilaksanakan pada materi dengan dua standar kompetensi yang dilakukan dalam dua siklus penelitian. Siklus pertama mencakup ma- teri dengan standar kompetensi "Siswa mampu merencanakan, melaksanakan, dan mengkomunikasikan hasil penelitian dengan menerapkan sikap ilmiah" yang terdiri atas kompetensi dasar (1) merencanakan penyelidikan ilmiah dalam bidang Biologi; (2) melaksanakan penyelidikan ilmiah dalam bidang Biologi; (3) mengkomunikasikan hasil penyelidikan ilmiah, dan (4) bersikap ilmiah. Siklus kedua mencakup materi dengan Standar Kompetensi "Siswa mampu memahami hakikat Biologi sebagai ilmu, menemukan objek dan ragam persoalan dari berbagai tingkat organisasi kehidupan yang ada di lingkungan sekitar" dengan Kompetensi Dasar: mempelajari ruang lingkup Biologi, manfaat, dan bahayanya.

Penelitian masing-masing siklus dilaksanakan melalui 4 tahapan, yaitu (1) perencanaan penelitian; (2) pelaksanaan tindakan; (3) observasi/evaluasi; dan (4) refleksi. Pelaksanaan penelitian tindakan kelas pada setiap siklus adalah sebagai berikut.

\section{a. Perencanaan}

Perencanaan penelitian dilaksanakan oleh guru Biologi (guru mitra). Kegiatan yang dilakukan pada bagian ini adalah (1) merencanakan penerapan model PBL untuk mengatasi masalah yang telah diidentifikasi yang dituangkan dalam Silabus dan Rencana Pelajaran (RP), (2) menyusun materi bahan ajar yang berupa suplemen bahan ajar, (3) menyusun LKS yang sesuai dengan penerapan model PBL, (4) menyusun tes tulis mengadaptasi bentuk tes (SOLO) Taxonomy beserta rubrik yang digunakan, tes unjuk kerja (performance assessment), dan menyusun tes sikap yang mengadaptasi dari Enger and Yager (2001), (5) merencanakan tek-nik pengumpulan data, dan (6) melatih guru dalam menerapkan pembelajaran, yaitu pembelajaran model PBL dan menerapkan asesmen yang digunakan.

\section{b. Pelaksanaan Tindakan}

Pelaksanaan tindakan yang berupa kegiatan pembelajaran di kelas dilaksanakan oleh guru mitra yang sebelumnya telah dilatih pada tahap 
perencanaan. Kegiatan yang dilakukan pada bagian ini adalah (1) menyebarkan pretes, (2) metelah memberikan pretes, guru membagi siswa dalam kelompok-kelompok kecil (4-5 orang), yaitu kelompok kooperatif Group Investigation, dan (3) melaksanakan proses pembelajaran, dengan menerapkan model PBL.

\section{c. Observasi/Evaluasi}

Observasi/evaluasi dilakukan oleh guru Biologi). Kegiatan yang dilakukan pada tahap ini adalah (1) memberikan tes tulis, yaitu tes (SOLO) Taxonomy untuk mengukur pemahaman konsep materi Biologi yang dipelajari, kemampuan memecahkan masalah Biologi, kemampuan menerapkan konsep Biologi, dan kemampuan berpikir kritis, (2) melaksanakan tes unjuk kerja (performance assessment), dengan tujuan: melengkapi pengukuran kemampuan memecahkan masalah Biologi dan kemampuan menerapkan konsep Biologi. Bentuk alat evaluasi ini adalah portofolio, (3) memberikan tes sikap, dengan tujuan mengukur sikap siswa terhadap pelajaran Biologi, (4) mencatat hal-hal penting yang terjadi dalam pembelajaran, dan (5) menjaring kendala-kendala atau kelemahan-kelemahan dan kelebihan-kelebihan dalam pembelajaran.

\section{d. Refleksi}

Refleksi dilakukan bersama oleh guru Biologi. Refleksi dilakukan pada setiap pembelajaran dan akhir siklus. Kegiatan yang dilakukan pada tahap ini adalah mengkaji atau menganalisis segala temuan pada tindakan, baik hasil tes tulis, tes unjuk kerja, hasil observasi, hasil pengamatan terhadap hal-hal penting yang terjadi selama proses tindakan, maupun penjaringan kendala-kendala atau kelemahan-kelemahan dan kelebihan-kelebihan selama proses pembelajaran. Hasil refleksi siklus pertama digunakan sebagai dasar perbaikan dan penyempurnaan perencanaan dan pelaksanaan tindakan pada siklus kedua.

Data dikumpulkan dengan menggunakan Tes SOLO Taxonomy untuk mengukur pemahaman konsep materi Biologi yang dipelajari, kemampuan memecahkan masalah Biologi, kemampuan menerapkan konsep Biologi, dan kemampuan berpikir kritis. Tes unjuk kerja (performance assessment) dalam bentuk portofolio, melengkapi pengukuran kemampuan memecahkan masalah Biologi dan kemampuan menerapkan konsep Biologi. Untuk memberi skor terhadap unjuk kerja siswa dibuat rubrik. Penyusunan Rubrik mengadaptasi dari Hart (1994). Tes sikap yang mengadaptasi dari Enger and Yager (2001), dengan tujuan mengukur sikap siswa terhadap pelajaran Biologi. Data yang diperoleh dianalisis secara deskriptif kuantitatif. Standar kompetensi minimal (SKM) individual terhadap penguasaan suatu kompetensi pada mata pelajaran Biologi dan kemampuan berpikir kritis di SMA Negeri 19 Bandung adalah $75 \%$.

\section{Hasil Penelitian dan Pembahasan}

Secara umum, pelaksanaan pembelajaran dengan menerapkan model PBL pada pelajaran Biologi dalam penelitian ini sangat baik. Dalam arti, siswa aktif melakukan kegiatan belajar dengan kegiatan mengidentifikasi dan merumuskan masalah dari masalah riil kehidupan yang disajikan dalam LKS, merancang investigasi, melaksanakan investigasi, mengumpulkan data /informasi melalui investigasi, membahas data /informasi yang diperoleh, mengajukan solusisolusi terhadap masalah yang diangkatnya, menyusun laporan, dan mempresentasikan laporan di hadapan kelas. Semua kegiatan belajar ini dilaksanakan dalam kelompok. Kelompok kelihatan sangat kompak dalam mengerjakan tugas belajarnya.

Peranan guru dalam pembelajaran penelitian ini adalah menyajikan masalah yang tidak terstruktur (melalui LKS), membimbing siswa dalam mengidentifikasi dan merumuskan masalah, membimbing siswa dalam merencanakan kegiatan investigasi, membimbing siswa dalam melaksanakan investigasi, membimbing siswa dalam menyusun laporan, membimbing siswa dalam menyajikan atau presentasi kelas. Satu hal yang juga dilakukan guru dalam pembelajaran 
ini adalah pada saat diskusi kelas, guru dapat memperbaiki kesalahan-kesalahan konsep siswa.

\section{a. Pemahaman Konsep Biologi}

Ringkasan hasil penelitian tentang pemahaman konsep Biologi pada siklus I dan siklus II disajikan dalam tabel 1.

Tabel 1 Pemahaman Konsep Biologi Siswa pada Siklus I dan

Siklus II

\begin{tabular}{|l|l|l|l|l|}
\hline \multirow{2}{*}{} & \multicolumn{2}{|c|}{ Siklus I } & \multicolumn{2}{c|}{ Siklus II } \\
\cline { 2 - 5 } & $\begin{array}{l}\text { Kelas X } \\
\text { MIA 5 }\end{array}$ & $\begin{array}{l}\text { Kelas X } \\
\text { MIA 6 }\end{array}$ & $\begin{array}{l}\text { Kelas X } \\
\text { MIA 5 }\end{array}$ & $\begin{array}{l}\text { Kelas X } \\
\text { MIA 6 }\end{array}$ \\
\hline $\begin{array}{l}\text { Ketuntasan } \\
\text { klasikal (\%) }\end{array}$ & 76,20 & 91,64 & 95,71 & 98,64 \\
\hline $\begin{array}{l}\text { Rerata skor } \\
\text { pemahan } \\
\text { konsep }\end{array}$ & 75,11 & 78,70 & 80,12 & 83,43 \\
\hline
\end{tabular}

Dari tabel 01, dapat diketahui sebagai berikut. (1) Pada siklus I, kelas X MIA 5 mencapai ketuntasan klasikal 76,20 \% dengan rerata skor 75,11; kelas X MIA 6 mencapai ketuntasan klasikal 91,64\% dengan rerata skor 78,70. (2) Pada siklus II, kelas X MIA 5 mencapai ketuntasan klasikal 95,71 \% dengan rerata skor 80,12; kelas X MIA 6 mencapai ketuntasan klasikal 98,64\% dengan rerata skor 81,43

Berdasarkan hasil ini, tampak bahwa kelas $\mathrm{X}$ MIA 5 pada siklus I, 23,80\% siswa belum tuntas. Banyaknya siswa kelas X MIA 5 yang belum tuntas kemungkinan disebabkan oleh siswa yang sebelumnya belum pernah mengikuti pelajaran dengan model ini, yang menuntut siswa benar-benar mandiri dan aktif dalam menggali materi pelajarannya. Berbeda dengan kelas X MIA 5, kelas X MIA 6 telah mencapai ketuntasan klasikal 91,64\%. Hal ini disebabkan oleh kelas X MIA 6 merupakan kelas dengan siswa yang yang memiliki kemampuan akademis lebih baik berdasarkan atas masukannya.

Namun, pada siklus II kedua kelas mencapai ketuntasan klasikal sangat baik $(95,71 \%$ dan $98,64 \%$ dengan rerata 80,12 dan 83,43 ).
Hal ini berarti, setelah siswa belajar lebih dari 1,5 bulan di siklus I, siswa telah mampu mengikuti pelajaran dengan model PBL ini. Dari hasil penelitian ini dapat dijelaskan bahwa, dengan menerapkan model PBL dalam pelajaran Biologi, pemahaman konsep Biologi kelas X MIA 5 dan kelas X MIA 6 meningkat.

Meningkatnya pemahaman konsep Biologi dengan menerapkan model PBL tidak terlepas dari kekuatan model ini dalam meningkatkan hasil belajar siswa. Meningkatnya pemahaman siswa disebabkan oleh siswa dalam pembelajaran ini membangun pengetahuannya melalui aktivitas belajar. Peranan guru sebagai pembimbing. Di samping itu, siswa dalam pembelajaran ini mengkaji masalah-masalah dalam kehidupan aktual siswa sehingga pembelajaran menjadi sangat bermakna. Konsep-konsep Biologi digali sendiri oleh siswa dan digunakan untuk memecahkan masalah yang sedang mereka hadapi, sehingga siswa mengalami aktivitas fisik dan mental. Oleh karena itu, pemahaman konsep Biologi menjadi lebih baik. Di samping itu, adanya diskusi dalam kelompok maupun klasikal akan lebih meningkatkan pemahaman siswa dalam materi pelajarannya. Walaupun terjadi kesalahan konsep pada siswa, guru dapat memperbaikinya saat diskusi kelompok maupun diskusi kelas.

\section{b. Kemampuan Memecahkan Masalah Biologi}

Ringkasan hasil penelitian tentang kemampuan memecahkan masalah Biologi pada siklus I dan siklus II disajikan dalam Tabel 02.

Dari Tabel 02, dapat diketahui sebagai berikut. (1) Pada siklus I, kelas X MIA 5 mencapai ketuntasan klasikal 68,82 \% dengan rerata skor 76,21 (31,18\% siswa belum tuntas); kelas X MIA 6 mencapai ketuntasan klasikal $75,78 \%$ dengan rerata skor 77,46 (24,22\% siswa belum tuntas). (2) Pada siklus II, kelas X MIA 5 mencapai ketuntasan klasikal 87,21 \% dengan rerata skor 78,65; kelas X MIA 6 mencapai ketuntasan klasikal 90,19\% dengan rerata skor 80,78 . 
Tabel 2 Kemampuan Memecahkan Masalah Biologi pada siklus I dan Siklus II

\begin{tabular}{|l|l|l|l|l|}
\hline \multicolumn{2}{|c|}{} & \multicolumn{2}{|l|}{ Siklus I } & \multicolumn{2}{l|}{ Siklus II } \\
\cline { 2 - 5 } & $\begin{array}{l}\text { Kelas X } \\
\text { MIA 5 }\end{array}$ & $\begin{array}{l}\text { Kelas X } \\
\text { MIA 6 }\end{array}$ & $\begin{array}{l}\text { Kelas X } \\
\text { MIPA 5 }\end{array}$ & $\begin{array}{l}\text { Kelas X } \\
\text { MIPA 6 }\end{array}$ \\
\hline $\begin{array}{l}\text { Ketuntasan } \\
\text { klasikal (\%) }\end{array}$ & 68,82 & 75,78 & 87,21 & 90,19 \\
\hline $\begin{array}{l}\text { rerata skor } \\
\text { kemampuan } \\
\text { memcahkan } \\
\text { masalah Biologi }\end{array}$ & 76,21 & 77,46 & 78,65 & 80,78 \\
\hline
\end{tabular}

Tingginya prosentase siswa yang belum tuntas pada siklus I kemungkinan disebabkan oleh kelas ini belum terbiasa belajar mandiri dan belum pernah diajarkan dalam memecahkan masalah Biologi yang ada di sekitar kehidupannya. Pada saat mereka di SMP, mereka masih terbiasa "disuapi" dengan materi pelajaran dan belum pernah dilatih memecahkan masalah aktual dengan menggunakan konsep-konsep yang mereka pelajari dari buku. Setelah mereka belajar lebih dari 1,5 bulan, maka pada akhir siklus II kemampuan memecahkan masalah Biologi mereka meningkat. Hal ini dapat dilihat dari hasil yang disajikan dalam Tabel 02. Pada siklus II, kelas X MIA 5 mencapai ketuntasan klasikal 87,21 \% dengan rerata skor 78,65, dan kelas X MIA 6 mencapai ketuntasan klasikal $90,19 \%$ dengan rerata skor 80,78 . Hasil penelitian ini menunjukkan bahwa kemampuan memecahkan masalah Biologi siswa yang belajar dengan model PBL mengalami peningkatan. Peningkatan kemampuan memecahkan masalah siswa ini kemungkinan disebabkan karena model ini dirancang untuk memecahkan masalah riil kehidupan dengan menggunakan konsep-konsep yang mereka pelajarai di kelas. Dalam pembelajaran, siswa dihadapkan pada masalah tidak terstruktur, kemudian siswa diharapkan mengidentifikasi dan merumuskan masalah. Pada langkah berikutnya, siswa dituntut untuk mencari jawaban dan solusi terhadap masalah yang mereka angkat. Dalam memecahkan masalah, siswa dituntut untuk mengumpulkan informasi atau data melalui proses investigasi. Pada saat ini siswa melakukan deduksi, induksi, evaluasi sehingga menghasilkan kesimpulan dan solusi terhadap masalah tersebut. Melalui proses belajar seperti ini, jelas nampak bahwa model PBL ini melatih siswa dalam memecahkan masalah, khususnya masalah Biologi.

\section{c. Kemampuan Menerapkan Konsep-Konsep Biologi pada Siklus I dan Siklus II}

Ringkasan hasil penelitian tentang kemampuan menerapkan konsep-konsep Biologi pada siklus I dan siklus II disajikan dalam tabel 03.

Tabel 3 Kemampuan Siswa Menerapkan Konsep-Konsep Biologi pada Siklus I dan Siklus II

\begin{tabular}{|c|c|c|c|c|}
\hline & \multicolumn{2}{|l|}{ Siklus I } & \multicolumn{2}{|c|}{ Siklus II } \\
\hline & $\begin{array}{l}\text { Kelas } \\
\text { X MIA } \\
5\end{array}$ & $\begin{array}{l}\text { Kelas } \\
\text { X MIA } \\
6\end{array}$ & $\begin{array}{l}\text { Kelas } \\
\mathrm{X} \\
\text { MIA } 5\end{array}$ & $\begin{array}{l}\text { Kelas } \\
\mathrm{X} \\
\text { MIA } 6\end{array}$ \\
\hline $\begin{array}{l}\text { Ketuntasan } \\
\text { klasikal (\%) }\end{array}$ & 79,11 & 80,24 & 80,24 & 90,11 \\
\hline $\begin{array}{lr}\text { rerata } & \text { skor } \\
\text { kemampuan } & \\
\text { menerapkan } & \\
\text { Biologi } & \end{array}$ & 75,78 & 77,69 & 81,65 & 82,30 \\
\hline
\end{tabular}

Dari tabel 03, dapat diketahui sebagai berikut. (1) Pada siklus I, kelas X MIA 5 mencapai ketuntasan klasikal 79,11\% dengan rerata skor $75,78 \quad(20,89 \%$ siswa belum tuntas); kelas X MIA 6 mencapai ketuntasan klasikal 80,24 \% dengan rerata skor 78,24 (19, $76 \%$ siswa belum tuntas). (2) Pada siklus II, kelas X MIA 5 mencapai ketuntasan klasikal $87,21 \%$ dengan rerata skor 78,65; kelas X MIA 6 mencapai ketuntasan klasikal 90,21 \% dengan rerata skor 82,30 .

Data Tabel 03 menunjukkan terjadi peningkatan kemampuan siswa dalam menerapkan konsep Biologi dari siklus I ke siklus II. Peningkatan kemampuan siswa dalam menerap- 
kan konsep Biologi disebabkan oleh kekuatan model PBL dalam melatih siswa dalam memecahkan masalah. Seperti dikemukakan di atas (bahasan kemampuan memecahkan masalah), bahwa model PBL dapat melatih siswa dalam memecahkan masalah baik masalah aktual maupun masalah akademis. Meningkatnya kemampuan memecahkan masalah sejalan juga dengan kemampuan menerapkan konsep (khususnya dalam pelajaran Biologi). Untuk dapat memecahkan masalah, siswa harus melakukan deduksi maupun induksi (kususnya dalam kajian ini adalah deduksi). Siswa yang tidak memahami konsep dengan baik, tidak akan dapat menerapkan konsep-konsep tersebut dengan baik untuk memecahkan masalah. Oleh karena itu, makin sering siswa dilatih memecahkan masalah dalam pembelajaran melalui model PBL, maka kemampuan siswa dalam menerapkan konsep tersebut dalam memecahkan masalah menjadi lebih baik pula. Jadi, model PBL dapat dengan baik melatih kemampuan siswa dalam menerapkan konsep.

\section{d. Kemampuan Berpikir Kritis Siswa pada Siklus I dan Siklus II}

Ringkasan hasil penelitian tentang kemampuan berpikir kritis pada siklus I dan siklus II disajikan dalam tabel 0.4 .

Tabel 4 Kemampuan Siswa dalam Berpikir Kritis pada Siklus I dan Siklus II

\begin{tabular}{|l|l|l|l|l|}
\hline \multirow{2}{*}{} & \multicolumn{2}{|l|}{ Siklus I } & \multicolumn{2}{l|}{ Siklus II } \\
\cline { 2 - 5 } & $\begin{array}{l}\text { Kelas } \\
\text { X }\end{array}$ & $\begin{array}{l}\text { Kelas } \\
\text { X MIA }\end{array}$ & $\begin{array}{l}\text { Kelas } \\
\text { X } \\
\text { MIA 5 }\end{array}$ & $\begin{array}{l}\text { Kelas } \\
\text { X MIA } \\
6\end{array}$ \\
\hline $\begin{array}{l}\text { Ketuntasan klasikal } \\
(\%)\end{array}$ & 71,89 & 75,82 & 82,81 & 92,51 \\
\hline $\begin{array}{l}\text { Rerata skor kemam- } \\
\text { puan berpikir kritis }\end{array}$ & 76,91 & 78,91 & 79,25 & 78,61 \\
\hline
\end{tabular}

Dari tabel 04, dapat diketahui sebagai berikut. (1) Pada siklus I, kelas X MIA 5 mencapai ketuntasan klasikal 71,89\% dengan rerata skor $76,91 \quad(28,11 \%$ siswa belum tuntas); kelas X MIA 6 mencapai ketuntasan klasikal $75,82 \%$ dengan rerata skor 78,91 (24,18\% siswa belum tuntas). (2) Pada siklus II, kelas X MIA 5 mencapai ketuntasan klasikal $82,81 \%$ dengan rerata skor 79,25; kelas X MIA 6 mencapai ketuntasan klasikal 92,51\% dengan rerata skor 78,61.

Berpikir kritis yang dimaksud dalam penelitian ini adalah proses terorganisasi yang melibatkan aktivitas mental yang mencakup kemampuan merumuskan masalah, memberikan argumen, melakukan deduksi, melakukan induksi, melakukan evaluasi, dan memutuskan serta melaksanakan dalam memecahkan suatu masalah.

Dengan model PBL, siswa melakukan proses belajar: membatasi masalah dari masalah yang illstructured, merumuskan masalah, merumuskan jawaban sementara terhadap masalah dengan mendeduksikan konsep-konsep, merencanakan invstigasi untuk mengumpulkan data, melakukan investigasi, melakukan eksplanasi, menyimpulkan, dan memutuskan rekomendasi solusi terhadap masalah yang sedang dihadapi. Dengan latihan seperti ini, jelas siswa yang belajar dengan model PBL terlatih dalam merumuskan masalah, memberikan argumen, melakukan deduksi, melakukan induksi, melakukan evaluasi, dan memutuskan serta melaksanakan dalam memecahkan suatu masalah.

\section{e. Sikap Siswa terhadap Pelajaran Biologi pada Siklus I dan Siklus II}

Ringkasan hasil penelitian tentang sikap siswa terhadap pelajaran Biologi pada siklus I dan siklus II disajikan dalam tabel 05.

Dari tabel 05, dapat diketahui sebagai berikut. (1) Pada siklus I, siswa kelas X MIA 5 yang sikapnya positif terhadap pelajaran Biologi mencapai 95,89\%; siswa kelas X MIA 6 yang sikapnya positif terhadap pelajaran Biologi mencapai 98,2\%. (2) Pada siklus II, siswa kelas $\mathrm{X}$ MIA 5 yang sikapnya positif terhadap pelajaran Biologi mencapai 98,77 \%; siswa kelas X 
MIA 6 yang sikapnya positif terhadap pelajran Biologi mencapai 98, $56 \%$.

Tabel 5 Sikap Siswa pada Pelajaran Biologi pada Siklus I dan Siklus II

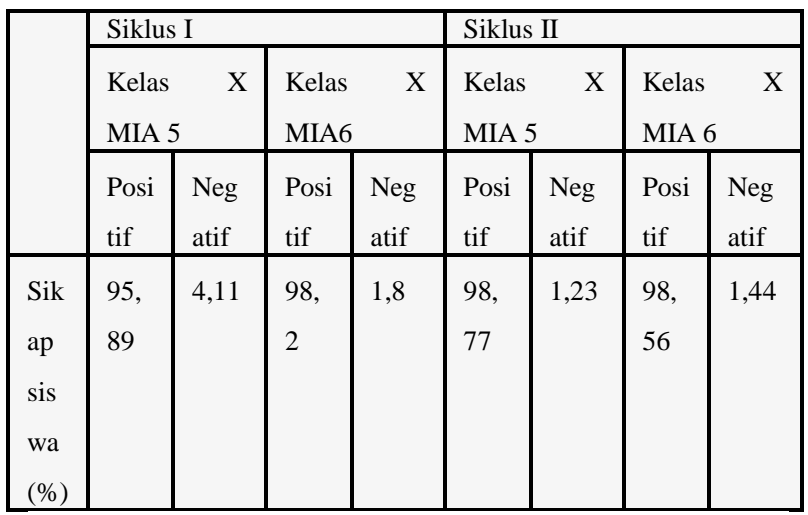

Tabel 5 menunjukkan bahwa secara umum siswa bersikap positif terhadap pelajaran Biologi. Hal ini menunjukkan bahwa siswa yang belajar dengan model PBL dapat meningkatkan minat belajar siswa dan meningkatkan sikap positif siswa terhadap pelajaran Biologi. Dari hasil refleksi diri siswa yang ditulis dalam portofolio terungkap bahwa siswa sangat senang mempelajari Biologi, apa lagi disertai dengan mengkaji masalah-masalah autentik yang terkait dengan kehidupan sehari-hari, sehingga siswa merasakan bahwa pelajaran seperti ini sangat bermakna baginya. Di samping itu, komentar siswa terhadap pelajaran Biologi adalah (1) Biologi adalah ilmu yang menyenangkan karena Biologi sangat dekat dengan kehidupan siswa, (2) berusaha menguasai Biologi karena ingin melanjutkan ke perguruan tinggi yang dasar teorinya Biologi, (3) guru yang mengajar menyenangkan dan menarik, (4) dan lain-lainnya.

\section{Penutup}

Dari penelitian ini dapat dibuat simpulan sebagai berikut. (1) Model Belajar Berdasarkan Masalah atau Problem Based Learning (PBL) dapat meningkatkan pemahaman konsep Biologi siswa kelas X SMA Negeri 19 Bandung tahun pelajaran 2014/2015. (2) Model PBL dapat meningkatkan kemampuan memecahkan masalah Biologi siswa kelas X SMA Negeri 19 Bandung tahun pelajaran 2014/2015. (3) Model PBL dapat meningkatkan kemampuan menerapkan konsep-konsep Biologi siswa kelas X SMA Negeri 19 Bandung tahun pelajaran 2006/2007. (4) Model PBL dapat meningkatkan sikap positif siswa kelas X SMA Negeri 19 Bandung tahun pelajaran 2014/2015 terhadap pelajaran Biologi. (5) Model PBL dapat meningkatkan kemampuan berpikir kritis siswa kelas X SMA Negeri 19 Bandung tahun pelajaran 2014/2015.

Saran yang dapat diajukan dalam penelitian ini adalah sebagai berikut. (1) Para peneliti lain hendaknya menemukan model-model pembelajaran lain untuk meningkatkan kompetensi dan kemampuan berpikir tingkat tinggi siswa. (2) Para guru, khususnya guru Biologi dapat memilih model PBL dalam pembelajarannya untuk meningkatkan kompetensi, kemampuan berpikir, dan sikap siswa terhadap pelajaran Biologi. (3) Para guru hendaknya mengubah paradigma pembelajarannya dari teacher centered ke student centered dengan menerapkan model PBL.

\section{DAFTAR PUSTAKA}

Arends, R.I. 2004. Learning to Teach. New York: McGraw-Hill

Enis, R.H. 1985. Goals for A Critical Thiking Curriculum. Costa, A.L. (Ed). Developing Minds A Resource Book for Teaching Thinking. (hlm. 54-57) Alexandra, Virginia: Assosiation for Supervisions and Curriculum Development (ASCD).

Enger, S. K. and Yager, R. E. 2001. Assessing Student Understanding In Science. California: Corwin Press, Inc.

Fogarty, R. 1997. Problem Based Learning and Other Curicular Models for Multiple Intellegences Classroom. New York: IRI/Skyligt Training and Publishing, Inc.

Gagne, R.M. 1980. Learnabel Aspects of Human Thinking. In: Lawson, A. E. (Ed). Science Education Information Report. (hlm. 1-28.) New York: The Eric 
Science, Mathematics and Environmental Education Clearing House .

Ibrahim, M. dan Nur, M. 2000. Pengajaran Berdasarkan Masalah. Surabaya: Unesa University Press.

Johnson, E. B. 2002. Contextual Teaching and Learning. Califorenia: Corwin Press, Inc.

Krulik, S. and Rudnik, J. A. 1996. The New Source Book Teaching Reasioning and Pbroblem Solving in Junior and Senior Hig School. Massachusets: Allyn \& Bacon.

Liliasari. 2000. Model Pembelajaran untuk Meningkatkan Keterampilan Berpikir Konseptual Tingkat Tinggi Calon Guru IPA. Proseding Seminar Nasional 23 Pebruari 2000. (hlm. 135-140). Malang: Dirjen Dikti Depdiknas-JICA-IMSTEP.

Marzano, R.J.et al. 1988. Dimension of Thinking A Framework for Curriculum and Instruction.Virginia: Assosiation for Supervisions and Curriculum Development (ASCD).

McNiff, J. 1992. Action Research Principles and Practice. London: MacMillan Education Ltd.
Pusat Kurikulum. 2002a. Kurikulum Berbasis Kompetensi. Jakarta: Balitbang Depdiknas.

Pusat Kurikulum. 2002b. Kegiatan Belajar Mengajar Kurikulum Berbasis Kompetensi. Jakarta: Balitbang Depdiknas.

Hosnan, M. 2014. Pendekatan Saintifik dan Kontekstual Dalam Pembelajaran Abad 21.Bogor : Ghalia Indonesia.

Pusat Kurikulum. 2002c. Kurikulum Berbasis Kompetensi. Jakarta: Pusat Balitbang Depdiknas

Rindell, A. J. A. 1999. Applying Inquiry-Based and Cooperative Group Learning Strategies to Promote Critical Thinking. Journal of College Science Teaching (JCST) 28(3): 203-207.

Tim Broad Based Education (BBE). 2002b.Pola Pelaksanaan Pendidikan Berorientasi Kecakapan Hidup (LifeSkill) Melalui Pendekatan Broad Based Education $(B B E)$. Buku II. Jakarta: Departemen Pendidikan Nasional RI.

Wheeler, S. 2002. Dual-Mode Delivery of Problem-Based Learning: A Constructivist Persfektif. (Online). http://searc hyahoo.com/search? p=problem + based + learning. Diakses 9 Maret 2003. 